Editorial

\section{Leucemia linfóide crônica: nova visão de uma velha doença (II Encontro Brasileiro de Consenso em LLC-B)}

\author{
Carlos S. Chiattone \\ Roberto P. Falcão
}

O conhecimento sobre a leucemia linfóide crônica (LLCB), a leucemia mais freqüente nos países ocidentais, sofreu uma verdadeira transformação nos últimos anos.

A visão clássica da LLC-B como doença homogeneamente indolente, de acúmulo lento e progressivo de linfócitos no organismo e de incidência em indivíduos idosos, com curta expectativa biológica de sobrevida, não mais se aplica com facilidade a todos os pacientes acometidos pela doença. A LLC-B é vista hoje como uma doença heterogênea, com um curso clínico variável.

Grande quantidade de informação sobre a natureza da célula neoplásica, incluindo alterações cromossômicas e moleculares, bem como mecanismos participantes na sobrevida do clone leucêmico, tem sido publicada recentemente.

Embora o estadiamento clínico, de Rai ou de Binet, ainda permaneça como o principal fundamento na antevisão do prognóstico, direcionando a decisão terapêutica, sabe-se hoje que cerca de $50 \%$ dos pacientes que se apresentam com estádio inicial da doença irão evoluir agressivamente, com rápida progressão e morte prematura pela LLC-B.

Entre os mais importantes recentes avanços no entendimento da LLC-B está a identificação, além do estadiamento clínico, de novos fatores prognósticos. Entre eles destacamse: o subgrupo de alteração citogenética, o estado mutacional da imunoglobulina, a expressão da ZAP-70 e a expressão do CD38. ${ }^{7}$ Estes novos fatores podem contribuir na identificação de pacientes com estádio clínico não avançado, mas com alto risco de rápida progressão da doença.

O leque de opções terapêuticas para a LLC-B se ampliou muito nos últimos anos, incluindo agentes alquilantes, análogos de purina e, mais recentemente, os anticorpos monoclonais. As combinações desses agentes (quimioimunoterapia), baseadas principalmente na observação de efeito sinérgico in vitro, têm sido muito estudadas recentemente, resultando em enorme melhoria nas taxas de resposta.

O tratamento de suporte, como estratégia de vacinação contra agentes infecciosos e correção de anemia, o acompanhamento sistemático para identificação precoce de segunda neoplasia e o manuseio adequado de infecções têm permitido marcada melhoria na qualidade de vida destes pacientes.
Por fim, mas não menos importante, está a definição dos critérios mínimos para o diagnóstico da LLC-B. A identificação cada vez mais freqüente de linfocitose monoclonal incipiente no sangue periférico por exames hematológicos de rotina, em indivíduos assintomáticos, é uma situação relativamente nova na prática hematológica, acarretando diversidade de opinião quanto à condução e à orientação destes "pacientes", inclusive sob o ponto de vista ético.

Frente a esta enorme quantidade de novos conhecimentos, através de iniciativa da SBHH e do $\mathrm{CBH}$, realizou-se em Salvador, Bahia, de 7 a 8 de outubro de 2005 o II Encontro Brasileiro de Consenso em LLC-B.

Diversos especialistas brasileiros foram convidados para relatar diferentes aspectos da LLC-B. O Prof. Guillaume Dighiero, do Instituto Pasteur de Paris, França, renomado pesquisador sobre o tema, foi convidado para auxiliar na mediação das discussões e nas conclusões do consenso.

O objetivo principal do encontro foi, após obtenção de consenso entre os membros do grupo, preparar um manuscrito atualizado de orientação aos especialistas brasileiros quanto à LLC-B, fornecendo, sobretudo, um enfoque racional do diagnóstico e da terapêutica da LLC-B, adaptado às peculiaridades brasileiras.

O resultado do II Encontro Brasileiro de Consenso em LLC-B é apresentado neste fascículo da RBHH.

\section{Chronic lymphocytic leukemia: A new vision of an old disease (II Brazilian Consensus Meeting on CLL-B)}

Carlos S. Chiattone
Roberto P. Falcão

Knowledge about chronic lymphocytic leukemia (CLLB), the most frequent type of leukemia in Western countries, has undergone a veritable transformation over the last few years.

The classic vision of CLL-B as a homogeneously indolent disease with a slow and progressive accumulation of lymphocytes in the organism and normally seen in elderly individuals who have a short expected biological survival time no longer is readily applicable to all patients stricken with the disease. CLL-B is seen today as a heterogeneous disease having a variable clinical course.

Much information on the nature of the neoplastic cell, including chromosomal and molecular alterations, as well as mechanisms which participate in the survival of the leukemic clone, has recently been published.

Although clinical staging, by Rai or Binet, still continues to be the principal foundation in the forecast of prognosis, 
guiding the therapeutic decision, it is known today that approximately $50 \%$ of the patients who present the initial stage of the disease will evolve aggressively, with a rapid progression towards a premature death.

Among the most important recent advances in the understanding of CLL-B is the identification, beyond clinical staging, of new prognostic factors. Among them the following stand out: the cytogenetic alteration subgroup, the mutational state of immunoglobulin, the expression of ZAP-70 and the expression of CD38..$^{7}$ These new factors can contribute towards the identification of patients in a non-advanced clinical stage, but with a high risk of a rapid progression of the disease.

The range of therapeutic options for CLL-B has been greatly extended over the last few years, including alkylating agents, purine analogs and, more recently, monoclonal antibodies. The combinations of these agents (chemoimmunotherapy), based principally on the observation of the synergic effect in vitro, have been studied in depth recently, resulting in an enormous improvement in the response rates.

The support treatment, such as a vaccination strategy against infectious agents and the correction of anemia, the systematic follow-up for the precocious identification of a second neoplasia and the adequate handling of infections, has made a marked improvement in the quality of life of these patients possible.

Last, but not least, there is the definition of the minimum criteria for the diagnosis of CLL-B. The identification ever more frequent of incipient monoclonal lymphocytosis in the peripheral blood by routine hematological exams performed on asymptomatic individuals is a relatively new situation in the hematological practice, incurring a diversity of opinions as to the conduction and orientation of these "patients", including from an ethical point of view.
In light of this enormous quantity of new knowledge, through the initiative of the $\mathrm{SBHH}$ and the $\mathrm{CBH}$, the "II Brazilian Consensus Meeting on CLL-B" was held in Salvador, Bahia, on October 7-8, 2005.

Many Brazilian specialists were invited to report on different aspects of CLL-B. Professor Guillaume Dighiero, of the Pasteur Institute of Paris, France, renowned researcher on the theme, was invited to assist in the mediation of discussions and in the conclusions of the consensus.

The main objective of the encounter, once the consensus among the members of the group had been obtained, was to prepare an updated manuscript for the orientation of Brazilian specialists on CLL-B, above all providing a rational focus on the diagnosis and therapy for CLL-B adapted to the Brazilian setting.

The result of the II Brazilian Consensus Meeting on CLL-B is presented in this issue of the RBHH.

Carlos Sergio Chiattone

President of the Sociedade Brasileira de Hematologia e Hemoterapia

Roberto Passetto Falcão

President of the Colégio Brasileiro de Hematologia

Correspondence to: Carlos S. Chiattone

Faculdade de Ciências Médicas da Santa Casa de São Paulo, Disciplina de Hematologia e Oncologia. Hemocentro da Santa Casa de São Paulo.

Rua Marquês de Itu, 579 - Vila Buarque

01223-001 - São Paulo, SP, Brazil

E-mails:dir.bs@santacasasp.org.br; carlos.chiattone@terra.com.b 